\title{
Land Administration System structured Land rent residuals and China's urban sprawl - A Case Study of Dashi, Guangzhou
}

\author{
Liu Xuan and Li Xun \\ Liu Xuan, School of Geography and Planning, Sun-Yat Sen University, Guangzhou, P. R. China \\ (liuxuan3@mail.sysu.edu.cn) \\ Li Xun, School of Geography and Planning, Sun-Yat Sen University, Guangzhou, P. R. China
}

\begin{abstract}
Urban sprawl has been at the centre of current debate on urban structure. Compared to the rich literature on urban sprawl in Western cities, relatively little is known about the physical consequence and the causes of urban sprawl in China. In China, for peasant collective-owned land (COL), land use right cannot be sold, transferred or leased for non-agricultural construction'. COL could be developed until it is acquired and leased out by the government. Through the process of land acquisition, the peasants could only get the compensation for 30 years' average of annual agricultural production value in addition to compensation for attachments, crops and vegetables which sometimes could hardly support the life of peasants who lost their land. To compensation for the peasants' loss, the government would leave 10-15\% of the acquired land to peasant collectives as Collectively Owned Economic Development Land (COEDL), allowing it used for industrial or commercial purpose. However, development of COEDL manifested to have low development density, quality and output. With a property rights approach, this research evaluates the development process of COEDL in Guangzhou. It has been revealed that high cost to obtain the permit of land use change (nongzhuanyong zhibiao), and to provide infrastructure and public facilities reduce the incentives of peasants to use COEDL legally and more efficiently. Furthermore, as COEDL is forbidden to transfer or mortgage, the financing ability of peasant collectives is thus impaired severely, allowing them only low investment on development. Use of COEDL thus contributes to urban sprawl in China.
\end{abstract}

Keywords: urban sprawl, Collectively Owned Economic Development Land (COEDL), property rights, Guangzhou, China

\section{Introduction}

Recently, much attention has been paid to discontinuous and often leapfrog development in peripheral areas of Chinese cities - regarded as urban sprawl. Largescale development zones, urbanized villages and large-scale gated communities in rural areas have been noticed and reported (Yeh and Wu 1996; Lin 2001; Tan et al. 2005). Taking Guangzhou as the example, both its economy and population have grown very rapidly since the 1980s, and the size of the built area has increased more than the population has (Table 1). The authors conducted a study in Dashi - a town located in the northern part of Panyu, a southern district of Guangzhou - to discover what happens in peripheral areas of Guangzhou. Observations reveal that development zones and large-scale gated communities interweave with villages and agricultural land. Almost all the development occurred in a discontinuous and often leapfrog manner, forming a typical urban sprawl landscape (see Figure 1). 
Table 1: Expansion of Built Area of Guangzhou

\begin{tabular}{ccccccc}
\hline Year & 1980 & 1985 & 1990 & 1995 & 2000 & 2005 \\
\hline Population $^{1}$ & 5.02 & 5.45 & 5.94 & 6.47 & 7.01 & 7.50 \\
Built area $^{2}$ & 135.96 & 162.92 & 187.40 & 259.10 & 431.5 & 734.99 \\
\hline
\end{tabular}

Note: 1 unit: million; 2.unit: $\mathrm{km}^{2}$

Source: Urban Planning Bureau of Guangzhou, accessed on 10 Sep. 2007

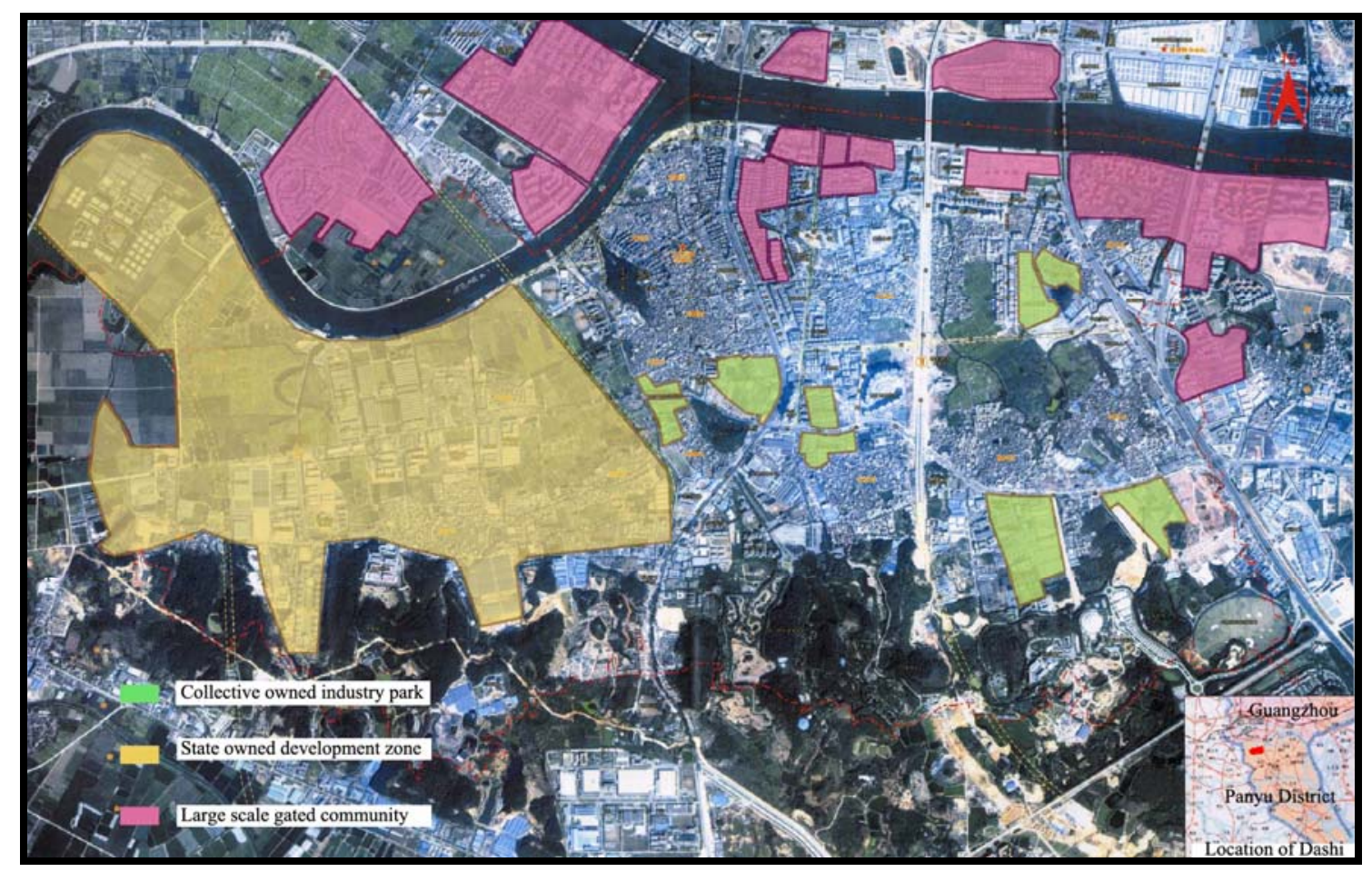

Figure 1: Land Use in Dashi (source: author's survey).

Scholars are wondering what causes the instances of large-scale sprawl in China, especially the unique patterns of such sprawl. Existing research has attributed China's urban sprawl to the post-reform land market forces, and to the changes in power distribution over urban development (Liu and Wei 1997; Zhang 2000).

However, The urban areas are expanding with constant definition and redefinition of property rights over land (Zhu 2004). Voluntary exchange cannot flourish and develop into firms and markets without institutions to assign, arbitrate and protect private property rights (Webster and Lai 2003). Land property rights thus matter for the performance of urban expansion (Fischel 1999). This article aims to explore the mechanism for urban sprawl in China via a property rights approach. Following a critique of the existing literature, a hypothesis of "land rent residual" is introduced based on the analysis of land administration system (LAS) in China to explain that there is a single mechanism that produces differing types of sprawl. We believe that this type of study will be helpful for exploring some of the driving forces behind China's urban expansion (Fung 1981; Wu and Yeh 1999; Logan 2001; Ho and Lin 2003) and accounting for urban sprawl in different contexts (McDonald 1993; Parker 1995; Richmond 1995; Freilich and Peshoff 1997). 


\section{Literature review: a critique}

Naughton first noticed the spillover of urban activities into suburban regions and concluded sprawl in China is mostly a result of changing internal economic forces that brought previously urban economic activities into peripheral areas (Naughton 1995). In addition to the expansion of urban activities into farmland, sprawl in the Chinese context is also believed to result from the sprawl of state power. State priority placed on certain types of developments and locations bears some responsibility for sprawl. A review of existing studies reveals that the studies offer common definitions but different explanation for three types of 'urban sprawl' in China.

\section{Development Zones}

Chinese local governments have set up a large number of 'development zones' that are often large and not connected with existing built up areas. Especially when considering that transportation in China still relies heavily on mass transit, such development zones can best be characterized as leapfrog development at a macro-level (Deng and Huang 2004). The boom in development zones have been studied from political perspectives (Huang and Yang 1996; Zhou 1997; Cartier 2001). Existing studies put forth two important forces behind the development zone phenomenonlocal government's desire for economic development and their thirst for fiscal revenue from the leasing of public land-which are related to China's decentralized fiscal system and the changing structure of local public finance (Deng and Huang 2004).

\section{Large-Scale Residential Projects}

Recently, scholars have noticed an increasingly commonplace phenomenon in China: low-density settlements of large, single-family houses reachable only by automobiles on networks of new roads, occupied exclusively by middle- and upperclass residents, and often gated and governed by restrictive covenants (Tan et al. 2005). Real estate development in the periphery has been categorized as 'amenity migration'the purchasing of primary or second residences in rural areas valued for their aesthetic, recreational, and other consumption-orientated use values (McCarthy 2008). It is believed that increases in the mobility of elites, rapid growth in relative and absolute incomes for certain classes of urban professionals, ongoing reductions in the friction of distance through developments in transportation and communications technologies, and the increased circulation of representations of prized rural landscapes are the main reasons for the emergence of large scale gated communities (Buckley 2003; Darling 2005; Gogia 2006; Moss 2006).

\section{Urbanized Villages}

Rural villages on the urban fringe have also developed quickly since the reform, although some scholars emphasize economic and physical development of such villages actually lags behind the population expansion (Deng and Huang 2004). Separate bodies of literature on urbanized villages have developed along two different veins. In the first vein, researchers are more interested in the social aspects of these villages such as ethnicity and culture (Ma and Xiang 1998). The second approach is more spatially based. For instance, Leaf looked at those villages from a broader perspective of rural urbanization (Leaf 2002). Based on a study on metropolitan development and spatial restructuring in the Pearl River Delta, Lin also argued that such development is largely driven by rural industrialization (Lin 2001). Such arguments are extensions of studies of the uniqueness of rural industrialization and rural-urban transition in Asian countries by McGee (1991). Desakota, a term coined by him, is basically a form of urbanization of 
the countryside first observed in Indonesia (McGee 1991). However, it is more a description of new spatial structures, with a relatively vague explanation of the driving forces.

Existing studies on development zones, urbanized villages and large-scale gated communities have been quite separate from one another. A macro-spatial perspective that links the three phenomena in the context of urban structure is missing in the literature. Any inquiry on urban structure, especially the urban fringe, and urban sprawl must deal with how rural land is developed into urban land and also discuss property rights over land. Therefore the evolution of China's Land Administration System which defines property rights over land - becomes an important factor to our analysis.

\section{China's Land Administration System}

For rural land

Since 1978, a series of market-oriented transformations have been initiated to stimulate economic development. Land reform is a major component of these reforms. In rural areas, the household contract responsibility system (HCRS) return land use rights to individual farmers by allocating collective land resources to individual farm households via contract. It is an institutional arrangement in which plots are contracted to farm households for cultivation while the right to dispose of the land remains with the collective. However, there were no laws dealing with land use and administration. So the occupation, use, transfer and management of rural land were not subject to any formal criteria. Consequently, some farmers 'illegally' sold, rented and mortgaged the land which they contracted from collectives. In the meantime, "Regulations for Developing Commune/Village Owned Enterprises (draft)" (Guangyu fazhan shedui qiye ruogan wenti de guiding (shixing cao'an)) was issued in 1979, stimulating the flourishing of township and village enterprises (TVEs) (Wu 2008). An increasing amount of collective land was thus 'illegally' occupied and developed. From 1982 to 1986 about 10 million cases of illegal land occupation occurred throughout the country (Qu 1991).

Since 1985 the state has taken quick responses to such problems. Land Administrative Bureaus (LAB) were established at various levels of government to: deal with applications for non-agricultural land use, survey land resources, design general land use plans, and supervise land use patterns and land quality changes, etc. Quotas for land use change from agricultural to non-agricultural sectors are decided by the central government based on China's national land use plan and are distributed to provinces and cities. Local LAB then allocate the quotas to different economic sectors. Farmer collectives - as the owners of collective owned land - are strictly forbidden from developing agricultural land without the approval of local LAB. Regulated by Land Administration Law, collective owned land is banned from sale, rent, transfer and mortgage for non-agricultural development ( $\mathrm{Pu}$ and Li 1998). Thus, the ownership of rural collective land is incomplete. In most cases, only after land acquisition by the government, may rural land be developed. However, there is still one way that collective owned land may be developed. After the government's land acquisition, the government might leave $10-15 \%$ of the acquired land to farmer collectives as economic development land (EDL), for industrial or commercial purposes. Such land could be rented, but is also forbidden from sale, transfer and mortgage. 


\section{For urban land}

Simultaneously with the reforms on rural land, a sentence stating that 'the right of land use of state owned land can be transferred in accordance with the law' was incorporated into Article 10 of the Constitution in 1988, initiating the paid transfer of land use rights (LURs) in urban areas. Urban land is no longer issued and supplied free. LURs for certain time durations (such as 40, 50 and 70 years) could be obtained by negotiations, tenders, and auctions, and could be transferred to others in the land market (Li 1999). In other words, within those certain time durations, land use rights over stateowned urban land is complete. In practice, local-level governments were responsible for LURs transfer activities (Keng 1996; Xu 1997; Zhang 1997). Land lease payment became the most important part of local government's "Extra-budget Revenue" (EBR). EBR consists of tax surcharges and user fees levied by local level government agencies. Unlike state allocated budgetary revenues, the local government need not share EBR with the central government. So EBR has become the main source for local infrastructure investment. Because urban construction in the pre-reform era lagged behind the citizens' requirement for living conditions and budgetary funds were far from enough to support infrastructure construction needs, it is easy to see why there was local enthusiasm for land leasing and urban development.

With the establishment of new the land administration system, the legal urban expansion process became a sole process of rural land changing to urban land, together with the process of incomplete collective ownership changing to complete land use rights of the government and land leaseholders. This Dualistic system of property rights over land creates uneven values between rural and urban land, which then arouses local interest for urban expansion, and finally to urban sprawl. To investigate the 'urban sprawl' mechanism in a more detailed way, this paper introduces the term 'land rent residual' to explain the urban sprawl process.

\section{Hypothesis: Land rent residual in transitional china}

The 'traditional' shape of land use used to be characterized by convergence towards city centres following the bid rent function (Alonso, 1964). It could also explain the emergence of land rent residual (LRR). In this dual system of land property rights (Figure 2) that China has, land between $\mathrm{Q}_{1}$ and $\mathrm{Q}_{2}$ has to be acquired at the price set by the government (compensation to agricultural outputs $\left(\mathrm{P}_{3}\right)$, which is much lower than the price of land leasing) and then leased out at market price $\mathrm{P}_{1}$. LRR (gray area) thus emerges as revenues which could be claimed by the local government due to the disparity between the price to acquire rural land - which is very low due to the incomplete property rights - and price to lease out urban land - which is much higher due to complete property rights.

New LAS and the central government exclusion of EBR stimulate local government to chase as much as LRR as possible. However, to capitalize on LRR, the local government has to lease out the land, which means it has to increase the value of land to a point where potential land leasers feel it is profitable to rent and develop the land. Leapfrog development is thus carried out to increase land value. Detailed analysis of different types of urban sprawl using data from Dashi, the study area, is carried out. 


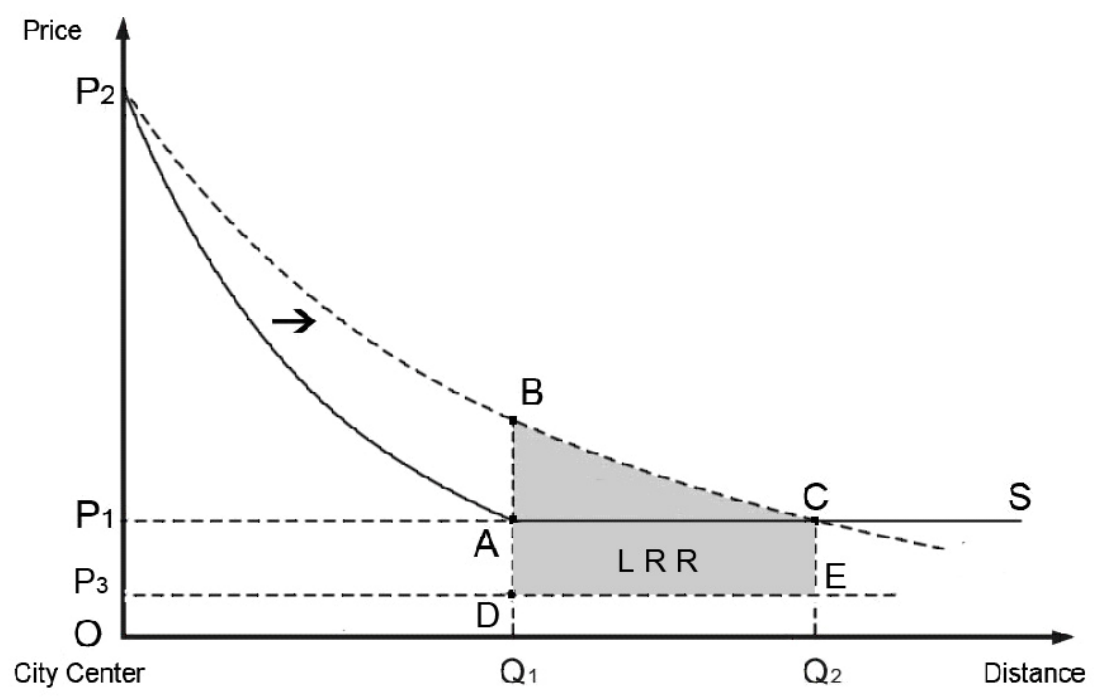

Figure 2: Land Rent Residual in China

\section{Application 1: Development Zone}

In Figure 3, the local government expands the urban boundary to $\mathrm{Q}_{4}$ although market forces would only push the boundary to $\mathrm{Q}_{2}$ by land acquisition. With the investment on infrastructure at a location beyond $\mathrm{Q}_{2}-$ taking $\mathrm{Q}_{3}$ as the example - local government successfully changes the bid rent curve for land use from PAC to PAFEG (with infrastructure investment cost of BDEG). Areas between $\mathrm{Q}_{2}$ and $\mathrm{Q}_{4}$ thus become worth to develop. Leapfrog development emerge and LRR of gray area (ADEF+BHIG) is capitalized.

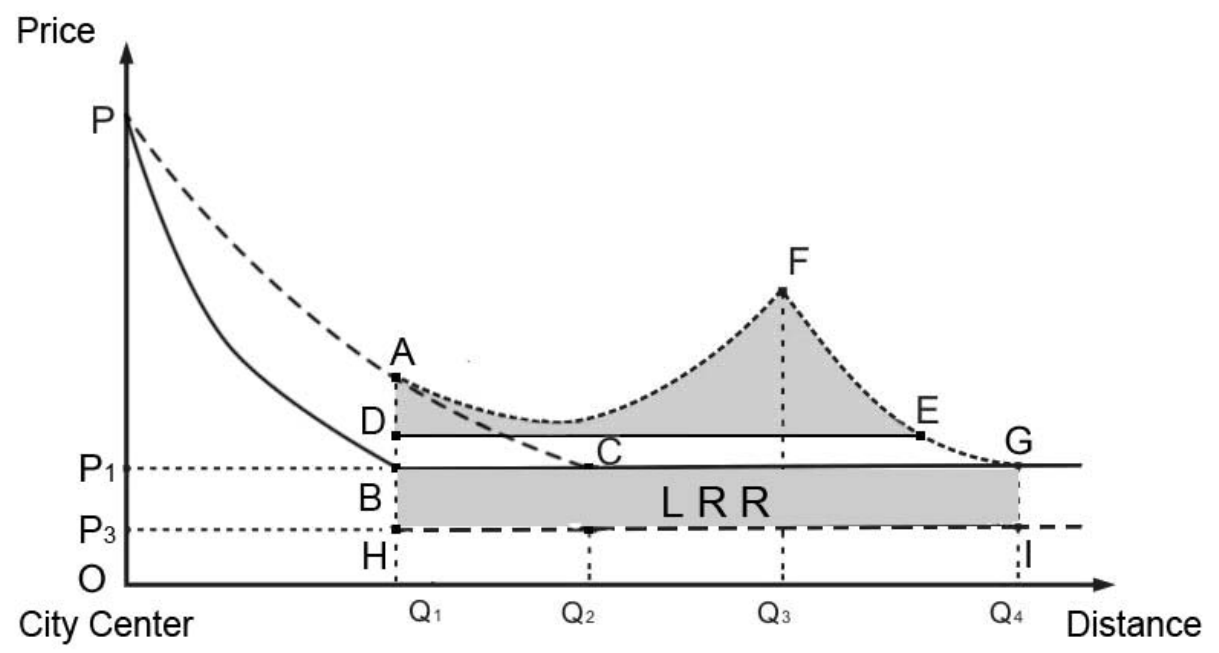

Figure 3: Leapfrog Development and Land Rent Residual

To capture the LRR with the least investment, the local government might apply two techniques. In the first case, the local government could acquire land, clear it, provide basic infrastructure and then lease it out for urban use. Referring to the Bid Rent Curve, industry would be the first party to use such land. Applying to build development zones would also be the easiest way to gain quota for development and to generate local tax for local government in China. In the second case, the local government could lease rural land to developers for residential projects if the land value is increased high enough. 
By 2003, there was over $10 \mathrm{~km}^{2}$ of land used for industry in Dashi, but the total output (industry value-added) was just 1.04 billion yuan, i.e. the output rate of industrial land is about $100 \mathrm{million} / \mathrm{km}^{2}$. This rate is just $1 / 10$ of the output rate of some areas in the Yangzi River Delta, such as Wenzhou (898.86 million/ $\mathrm{km}^{2}$ ) and Shaoxing (1.2 billion $\left./ \mathrm{km}^{2}\right)^{1}$. In Shibei Development Zone (the biggest development zone in Dashi, owned by the town government, area: $466 \mathrm{ha}$ ), modern electronics manufacturing facilities are surrounded by rural land and vacant plots. These rural and vacant parcels reduce the average output of the land. Developed land accounts for only $36.2 \%$ of the total area $^{2}$. The Dashi government acquired the land used for Shibei Development Zone through a deal that only compensated the individual villagers for 30 years' worth of average annual agricultural production in addition to compensation for attached land improvements, crops and vegetables - which generally amounts to 3000 yuan/ $\mathrm{ha}^{3}$ in the Pearl River Delta. The land was leased out at a very low price to attract large manufacturers to agglomerate. It was actually the annual income tax paid by those manufacturers that the local governments had targeted.

\section{Application 2: Large scale residential projects}

Under the same mechanism and behaviors that drove development of industrial zones, large residential projects are now found spread out in the urban periphery of Chinese cities. In middle 1990s, Panyu became the hotspot for residential development within Guangzhou. A multitude of large residential projects were developed along Huanan Expressway that the local government constructed in 1999. In Dashi, Lijiang Garden, Luoxi New Town, Xinghe Bay are all large residential projects covering over 100 ha each. Such projects were aimed at fulfilling the wants of Guangzhou citizens by providing bigger apartments and better facilities within a luxurious environment at relatively lower prices. Due to the poor condition of existing public facilities, the developers provided a variety of infrastructure and amenities within the residential projects. For example, Lijiang Bridge in Lijiang Garden and Zhixin Middle School (Xinghe Bay) were both provided by developers. Those and others were good quality facilities in order to attract the target customers (Figure 4). Xinghe Bay even built a well-designed wooden sightseeing boardwalk along the Back Channel of the Pearl River.

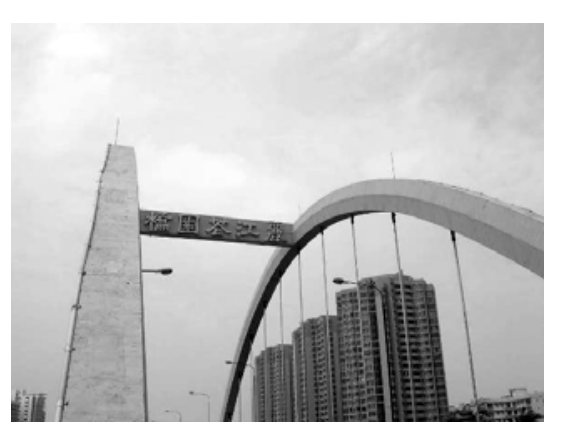

Figure 4: Public Facilities in Large Gated Communities in Dashi

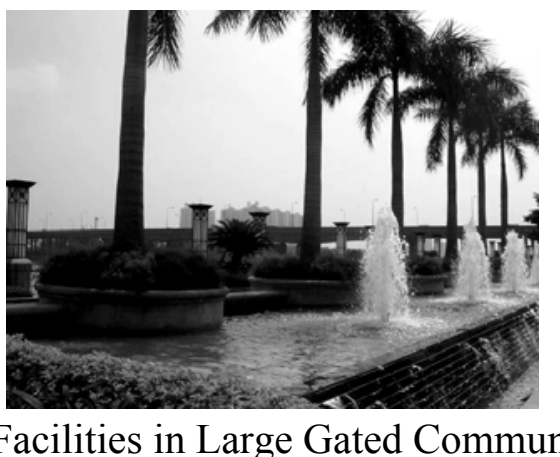

Source: photos taken by author

As one-off payments by developers to the government for land use eliminates the government from the potential for a long-term development profit, the local

\footnotetext{
${ }^{1}$ Source: 'Report on agglomeration plan for Panyu's industry zone' (2007), Panyu Planning Bureau internal working report. accessed on Nov. 7, 2007

${ }^{3}$ Source: interview to officials in Construction Service Centre of Dashi, on $8^{\text {th }}$ Nov, 2007.
} 
governments of Panyu and Dashi went so far as to create joint ventures with investors for real estate development. These joint ventures meaninvestors must cooperate with the government's subordinated development companies (Table 2). By sharing the shareholding, the local government not only enjoys the land lease payment but also shares in revenue from the sale of housing units.

Table 2: A Sampling of Joint Development Projects between Local Government and Investors Real Estate Projects in Dashi (Shareholding)

\begin{tabular}{|c|c|c|c|}
\hline Project name & $\begin{array}{l}\text { Government's development } \\
\text { company }\end{array}$ & Investor 1 & Investor 2 \\
\hline Xinghe Bay & $\begin{array}{l}\text { Panyu Unite Development Co. } \\
\text { Dashi Division }(30 \%)\end{array}$ & $\begin{array}{l}\text { Guangzhou Hongyu } \\
\text { Group. (51\%) }\end{array}$ & $\begin{array}{l}\text { Shenzhen Southern } \\
\text { Xiangjiang In. (19\%) }\end{array}$ \\
\hline Lijiang Garden & Panyu Unite Development Co. & Yuhai Group & \\
\hline Luoxi New Town & $\begin{array}{l}\text { Kaiyuan Real Estate Industry } \\
\text { Co. }\end{array}$ & $\begin{array}{l}\text { Yourong Ltd. Co. } \\
(\mathrm{HK})\end{array}$ & $\begin{array}{l}\text { Hengji Zhaoye } \\
\text { Development Co. (HK) }\end{array}$ \\
\hline
\end{tabular}

Source: archives of the Panyu Planning Bureau, accessed on 8 Jul, 2007

\section{Application 3: Urbanized villages}

As Lin highlighted, rural industrialization plays an important part in metropolitan development and spatial restructuring in the Pearl River Delta. It can also be explained by LRR. In fact, LRR captured by the local government through land leasing would inevitably stimulate the farmer collective - as the land owner - to rent their land out without changing its ownership. Under the legal system, land beyond $\mathrm{Q}_{1}$ won't be developed because the official land leasing price $\left(\mathrm{P}_{1}\right)$ is higher than potential land users would willing to pay (according to bid rent curve). In such cases, the government won't acquire rural land. This leaves an opportunity for existing land owners - farmer collectives - to rent land out at a price lower than $\mathrm{P}_{1}$ but higher than $\mathrm{P}_{3}$. Such development might be legal as each village is allowed to use a certain amount of land (EDL) for industrial or commercial purposes (although the village is not allowed to transfer title to that land). It may be illegal if the village changes land use types from agriculture to other use without permission from the local government. Due to the uncertainty of village behavior regarding land, development of collective owned land ends up being fragmented. In Figure 5, village 1 and village 2 rent $\mathrm{Q}_{2} \mathrm{Q}_{3}$ and $\mathrm{Q}_{4} \mathrm{Q}_{5}$ to factories, and capture the land value of CDEF and HGI.

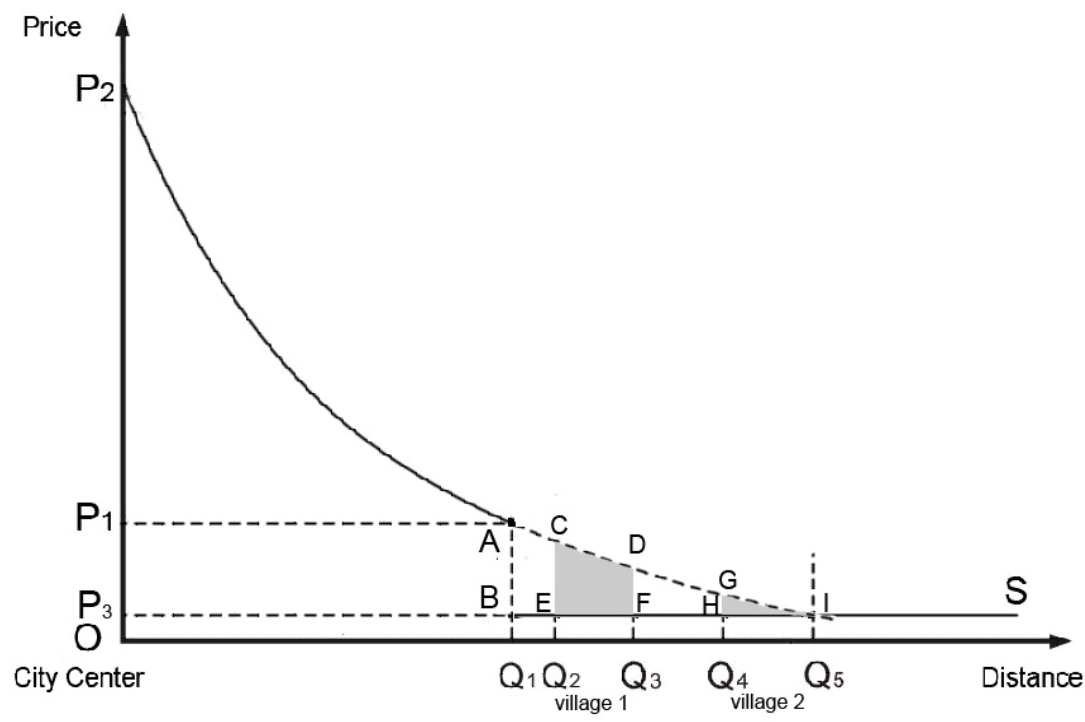

Figure 5: Development of Collective Owned Land 
Small industrial parks have been observed in every village in Dashi. Land in these industrial parks, which have poor infrastructure provision, is rented to various types of small factories. Rent is very low. For instance, in Beilian village, which is located in the northwest part of Dashi, the rent for workshops is $9-15 \mathrm{yuan} / \mathrm{m}^{2}$. As the duration of land rental contracts is ten or fewer years, factories are hesitant to invest significantly in infrastructure and fixed equipment. Workshops in these industry parks are thus poorly constructed and end up easily dilapidated (see Figure 6). The large numbers of small factories also require many migrants to work in them. Thus a demand for low price accommodations arises. Villagers construct small apartments on land allocated to individual village families and rent rooms to those workers.

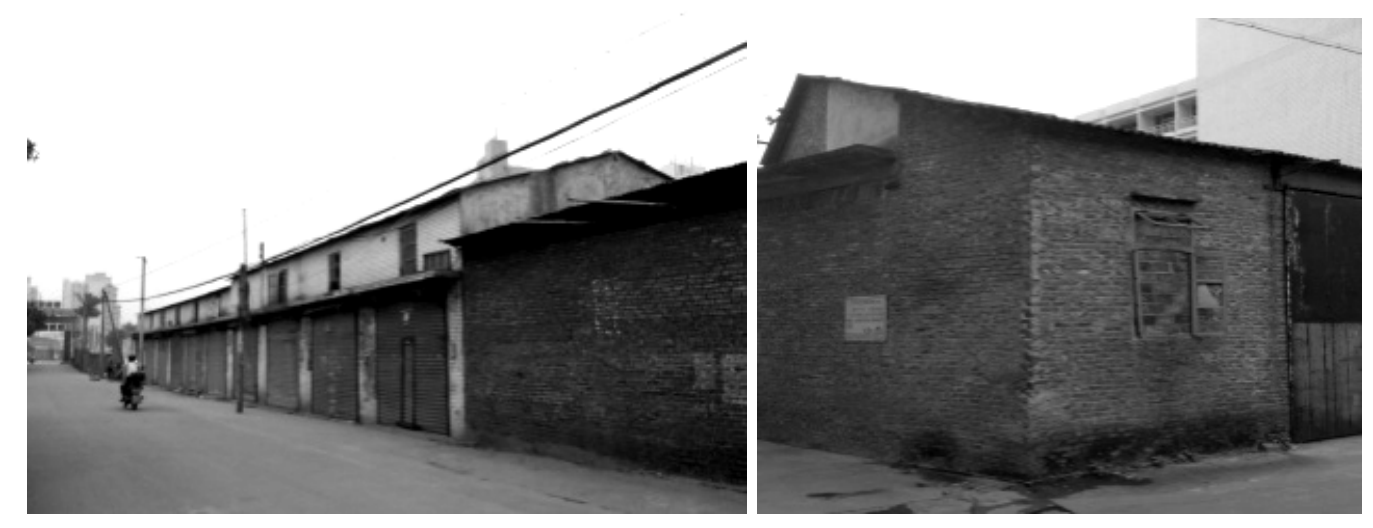

Figure 6: Small factories in villages (Beilian Village)

Source: photos taken by author

\section{Conclusion and discussion}

China's economic reforms over the past two decades have been partial and gradual . Partial reform can result in inefficient resource allocation at the interface of different sectors (Murphy et al. 1992). A typical case is LAS reform, which has successfully promoted the emergence of land markets and increased land use efficiency but also has created the problem of urban sprawl.

New land administration system endows complete land use rights over state owned land, yet incomplete land ownership over collective owned land, causing a gap between the rent of state and collective owned land. Land Rent Residual (LRR) thus emerges as an appurtenance of differing property rights over state and collective owned land induced by LAS reform.

As land leasing payments are the most important part of local Extra-budget Revenue, local governments tend to lease more land to capture LRR. In practice, local governments lease land for factories or big scale residential projects to capitalize LRR after they acquire land and provide basic infrastructures. LRR captured by the local government through land acquisition and leasing also stimulates the farmer collectivesas the land owner - to rent their land legally or illegally at a lower price than state owned land to capture part of LRR. Through the concept of LRR, it is easy to understand that uneven land reform causes the existence of an "envelope" between urban land and rural land. Undesirable consequences emerge on urban fringe. 
To a large extent, the problem of LRR seeking arise from remaining imperfections in the system of land administration, particularly ambiguous property rights, the limited competence of the land administrative organizations, and weak law enforcement, which all have negative effects on land use efficiency and cause the problem of urban sprawl. A number of options for further reform of rural LAS, especially with respect to land property rights, land marketing and the state administration system, have to been considered.

\section{References}

Alonoso, W. (1964), Location and Land Use (Massachusetts: Harvard University Press).

Buckley, R. (2003), 'The practice and politics of tourism and land management', in R. Buckley, C. Pickering and D. B. Weaver (eds), The practice and politics of tourism and land management (Cambridge, MA: CABI Publishing).

Cartier, C. (2001), 'Zone fever, the arable land debate, and real estate speculation: China's evolving land use regime and its geographical contradictions', Journal of Contemporary China 10: 28, 445-469.

Darling, E. (2005), 'The city in the country: wilderness gentrification and the rent gap', Environment and Planning A 37: 1015-1032.

Deng, F. F. and Huang, Y. Q. (2004), 'Uneven land reform and urban sprawl in China: the case of Beijing', Progress In Planning 61: 211-236.

Fischel, W. A. (1999), 'Does the American way of zoning cause the suburbs of metropolitan areas to be too spread out?' in A. Altshuler (eds), Does the American way of zoning cause the suburbs of metropolitan areas to be too spread out? (Washington, DC: National Academy Press).

Freilich, R. and Peshoff, B. (1997), 'The social costs of sprawl', The Urban Lawyer 29: 2, 183-198.

Fung, K. I. (1981), 'Urban sprawl in China: some causative factors', in L. J. C. Ma and E. W. Hanten (eds), Urban sprawl in China: some causative factors (Boulder: Westview Press).

Gogia, N. (2006), 'Unpacking corporeal mobilities: the global voyages of labor and leisure', Environment and Planning A 38: 359-375.

Ho, S. P. S. and Lin, G. C. S. (2003), 'Emerging land markets in rural and urban China: policies and practices', The China Quarterly 175: 681-707.

Huang, Y. and Yang, D. L. (1996), 'The political dynamics of regulatory change: speculation and regulation in the real estate sector', Journal of Contemporary China 5: 12, 171-185.

Keng, K. C. W. (1996), 'China's land disposition system', Journal of Contemporary China 5: 13, 235-248.

Leaf, M. (2002), 'A tale of two villages: globalization and peri-urban change in China and Vietnam', Cities 19: 1, 23-31.

Li, L. H. (1999), 'Impacts of land use rights reform on urban development in China', Review of Urban and Regional Development Studies 11: 3, 193-205.

Lin, G. C. S. (2001), 'Metropolitan development in a transitional socialist economy: spatial restructuring in Pearl River Delta, China', Urban Studies 38: 3, 383-406.

Liu, X. and Wei, L. (1997), 'Zhejiangcun: social and spatial implications of informal urbanization on the periphery of Beijing', Cities 14: 2, 95-108.

Ma, L. J. and Xiang, B. (1998), 'Native place, migration and the emergence of peasant enclaves in Beijing.' The China Quarterly 155: 546-581, 
McCarthy, J. (2008), 'Rural geography: globalizing the countryside', Progress in Human Geography 32: 129-137.

McDonald, J. (1993), 'Local property tax differences and business real estate values', Journal of Real Estate Finance and Economics 6, 277-287.

Mcgee, T. G. (1991), The Emergence of Desakota Regions in Asia: Expanding a Hypothesis (Honolulu: University of Hawaii Press).

Murphy, K., Shleifer, A. and Vishny, R. W. (1992), 'The transition to a market economy: pitfalls of partial reform', Quarterly Journal of Economics 107: 889906.

Naughton, B. (1995), Growing Out of the Plan: Chinese Economic Reform, 1978-1993 (Cambridge, MA: Cambridge University Press).

Parker, A. (1995), 'Patterns of federal urban spending: Central cities and their suburbs, 1983-1992', Urban Affairs Review 31: 2, 184-205.

$\mathrm{Pu}$, Y. and Li, Y. (1998), Explanations for P.R. China Land Administration Law (Beijing: Law Press).

Qu, F. T. (1991), On Land Institutions in China's Rural Area: 1949-1990 (Nanjing: Jiangsu People's Press).

Richmond, H. (1995), Regionalism: Chicago as an American Region (Chicago: The MacArthur Foundation).

Tan, M., Li, X., Xie, H. and Lu, C. (2005), 'Urban land expansion and arable land loss in China - a case study of Beijing-Tianjin-Hebei region', Land Use Policy 22: 187-196.

Webster, C. J. and Lai, L. W. C. (2003), Property rights, planning and markets: managing spontaneous cities (Cheltenham UK and Northampton MA, USA: Edward Elgar).

Wu, F. L. and Yeh, A. G. O. (1999), 'Urban spatial in a transitional economy: the case of Guangzhou, China', Journal of the American Planning Association 65: 4, $377-$ 394.

Wu, X. (2008), 30 Years's Transition: Chinese Enterprises from 1978-2007 (Beijing: China Citic Press).

Xu, P. (1997), 'Acquiring land use rights in China', China Law March, 94-96.

Yeh, A. G. O. and Wu, F. (1996), 'The new land development process and urban development in Chinese cities', International Journal of Urban and Regional Research 20: 2, 330-353.

Zhang, T. W. (2000), 'Land market forces and government's role in sprawl', Cities 17: 2, 123-135.

Zhang, X. Q. (1997), 'Urban land reform in China', Land Use Policy 14: 3, 187-99.

Zhou, Y. (1997), 'On the suburbanization of Beijing', Geographical Science (Di Li Ke Хие) 7: 3, 208-219.

Zhu, J. M. (2004), 'From Land Use Right to Land Development Right: Institutional Change in China's Urban Development', Urban Studies 41: 7, 1233-1251. 